\title{
STATE OF THE ART REVIEW ON BEHAVIOUR AND CALCULATION OF COMPOSITE PLATE SHEAR WALLS
}

\author{
Ivan Ćurković, Ivica Džeba
}

Subject review

Application of vertical stabilisation systems composed of frames with infilled panel has been increasingly adopted in nowadays buildings, primarily due to high resistance as well as their favourable behaviour when exposed to significant seismic activity. This paper has covered systems consisting of composite panels placed within the steel or composite member frames. These systems are listed in leading world norms, but the given guidelines are, due to insufficient research, very scarce and leave the designer with a number of opened questions. Aside these guidelines, this paper provides their additional clarification, and indicates the field's current state of the art which would be used to set the course of further research.

Keywords: composite plate shear walls; seismic activity; shear wall; vertical stabilisation

\section{Stanje područja ponašanja i proračuna sustava vertikalne stabilizacije koji koriste spregnuti ispun}

Pregledni članak

Primjena sustava vertikalne stabilizacije sastavljenih od okvira $\mathrm{s}$ umetnutim ispunom sve više nalazi mjesta $\mathrm{u}$ današnjim građevinama, prvenstveno iz razloga velike otpornosti kao i dobrog ponašanja uslijed značajnijih potresnih djelovanja. U radu su obrađeni sustavi sa spregnutim ispunom, te okvirom izvedenim od čeličnih ili spregnutih elemenata. Takvi su sustavi navedeni u normama, ali su dane smjernice, iz razloga nedostatne istraženosti, vrlo šture i ostavljaju mnogo otvorenih pitanja. Rad uz smjernice iz vodećih svjetskih normi navodi pojašnjenja istih, te dodatno ukazuje na sadašnje stanje područja na temelju čega je moguće iščitati smjernice za buduća istraživanja.

Ključne riječi: posmične stijene; seizmičko djelovanje; spregnuti ispun od čelika i betona; vertikalna stabilizacija

\section{Introduction}

Due to desire for construction of taller buildings as well as the development of design standards in the direction of seismic action implementation the problem of vertical stabilisation becomes more pronounced. Traditionally, vertical stabilisation of steel structures has been completed through use of diagonal bracing elements or moment resisting frames, as well as through insertion of reinforced concrete (RC) shear walls inside of steel or composite steel concrete boundary members.

Wider and more frequent application of steel in structural engineering led to development of other types of vertical stabilisation. Therefore, in the past 50 years, stabilisation using steel shear walls has been adopted within the structure of new buildings as well as within the structure of existing buildings as enhancement of the existing vertical stabilisation so-called seismic retrofit [1].

Although, generally, the application of shear walls has many structural and economic advantages, it also has some disadvantages.

The main disadvantage of reinforced concrete shear walls is the development of cracks in tension areas and localised concrete crushing in the compression zones during large cyclic displacements. Such concrete failures can result in serious deterioration of stiffness and reduction in strength of these systems. RC shear walls, compared to the steel ones, have relatively high weightto-strength ratio, which is from the standpoint of seismic behaviour, rather unfavourable.

On the other hand even though steel plate shear walls have more favourable weight-to-strength ratio their disadvantage is the buckling occurrence of the compression zone which results in reduced shear strength, stiffness and energy dissipation capacity. In addition, due to large inelastic deformations occurring in steel panels, the connections of the boundary frame can undergo large cyclic rotations as well as somewhat larger interstorey drifts [2]. From the above facts it follows that plate buckling must be precluded in order to ensure favourable behaviour of the system. This can be completed by increasing the steel plate thickness or by using stiffeners (very common in Japan), where both approaches, particularly the latter, imply significant cost increase. It should be also taken into consideration that welding of additional stiffeners weakens the system by introducing residual stresses and initial imperfections.

In response to these shortcomings, at the end of the last century, the idea was born that by combining advantages of each of the two materials, new system of vertical stabilisation can be developed. This new system utilises composite steel concrete panels and is termed composite plate shear wall. Such approach effectively restrains steel plate ensuring its global stability and allows development of full shear yield strength of the plate. Composite plate shear wall systems, in comparison to systems using RC panels, for the same shear capacity have smaller footprint and are lighter, which in turn reduces the effects on the columns, therefore having positive impact on sizing of the boundary members and the overall structure weight, and ultimately affects the foundation costs. Compared to steel plate shear walls, composite plate systems provide more stiffness, greater strength and better energy dissipation capacity for the same steel plate thicknesses. Additionally, during more frequent low and moderate size seismic events composite plate shear walls preclude steel plate buckling and concrete cracking where both might cause periods of occupancy interruption due to the necessary repairs [3]. 


\section{Composite plate shear wall definition}

Leading world construction norms (United States AISC 341[4] and European EN 1998-1 [5]) under composite panel imply steel plate with RC encasement on one or both sides of the plate, and structural steel or composite boundary members. The definition is additionally expanded in [4] where composite panel may be comprised of steel plates on both sides of the reinforced concrete infill. Various types of systems using composite plates are given in Fig. $1[4,6]$.

Up to date, most of conducted researches focused on systems with steel boundary frames infilled with steel plate and $\mathrm{RC}$ encasement mounted on one or both sides of the plate. Common name in the available literature for such systems is traditional composite plate shear walls implemented in [6]. Astaneh-Aslalso proposed system having a small gap between RC wall and boundary members, where the gap can be additionally filled with viscoelastic material, which will improve seismic behaviour by increasing energy dissipation capacity of the system, avoiding, at the same time, excessive damage of the RC wall. This newly proposed system was named innovative [6].
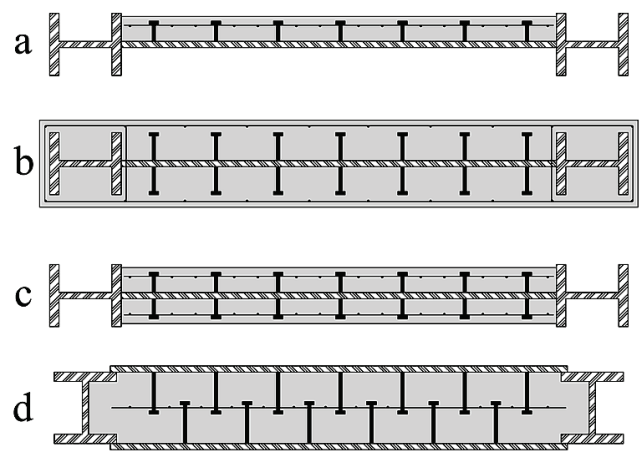

Figure 1 Various composite plate shear wall types $[4,6]$

Beside mentioned, other types of systems, considering connection of the infill panel to beam elements only, have been proposed, but since standards $[4,5]$ permit only continuous connection of the steel plate to boundary elements, these systems were ruled out from further consideration of this paper.

\section{System members and behaviour assumptions}

Plates are elements having two dominant dimensions which make them very slender, resulting with the fact that such elements have very low value of the critical buckling force. The investigations conducted in the early twentieth century found that despite the early buckling occurrence, of plates in state of pure shear, there is still possibility of their post-buckling strength exploitation, which should not be neglected [7]. Later work conducted by Kuhn et al. $[8,9]$ resulted in the fact that the final value of panel shear capacity can be calculated as the sum of plate pure shear capacity before buckling and remaining postbuckling capacity of the diagonal tension field.

The application of these theories in construction industry started in the 1960s when Basler [10] adjusted tension field theory for determination of plate girders shear resistance, until finally in the mid-1980s analytical models applicable to steel plate shear walls were developed $[11,12,13]$. Through observation of steel plate shear walls one can easily relate its behaviour to the cantilevered vertical plate girder. Despite this analogy appropriate for general understanding of these systems, it is important to note that these two systems can only be qualitatively compared as shown by Berman and Bruneau in [14]. The underlying difference is that shear wall system boundary members have significantly higher stiffness affecting the tension field inclination angle which considerably influences the strength of the system. Therefore, literal application of the plate girders calculation procedure can lead to steel plate shear walls with larger-than-expected strengths.

Observing the types of vertical stabilisation which use some kind of infill panels one can differentiate between flexure-dominated and shear-dominated walls. First behaviour is typical of the systems using very thick plates or stiffened plates, where major part of their inelastic deformation develops at the wall base. On the other hand, adoption of thin and unstiffened panels results in in shear-dominated behaviour where yielding of infill panels occurs in multiple storeys thus avoiding yielding at the wall base due to cantilever action as shown in Fig. 2 [15]. In this manner, similarly to the moment resisting frames, yielding due to shear action is distributed along the height, allowing high strength and ductility of these systems. a)

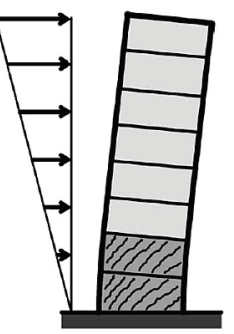

b)

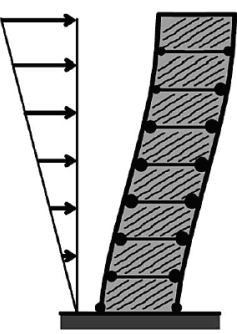

Figure 2 Vertical stabilisation types: a) flexure-dominated, b) sheardominated [15]

Well-known fact that plate resistance is greater if shear yield strength is achieved before the plate critical buckling force spurred the development of systems with restrained infills. Moreover, in systems using composite panels (especially in traditional systems) through activation of $\mathrm{RC}$ plate diagonal compression strut there is additional strength, but this contribution to the resistance of the system is not taken into account in design, which is conservative. Such an approach, depending on the size of the gap, can be justified for innovative composite plate shear wall systems.

At the same time, with increased resistance realised through use of composite panels, aside tensile there exist equivalent compressive stresses what has favourable impact on boundary members i.e. due to their interaction there will be no transverse force on the frame members usually exerted when the steel plate is not adequately restrained. Because of such behaviour design of connection between panel and the boundary elements should be conducted for the shear action only, while at the same time stiffness of the boundary members can be further reduced resulting in additional savings in material of these systems. 
Behaviour of joints between frame members in composite plate shear wall has not been sufficiently investigated. US provisions [4] predict application of composite panels within moment frames using rigid fullstrength beam-to-column joints. These kinds of guidelines are not listed in [5]. According to [4] moment frames can be constructed to have low, medium or high ductility or can be designed as dual systems where moment frames have high ductility and are capable of resisting at least $25 \%$ of prescribed seismic force. Both cases predict steel webs to be designed to resist total seismic load, and the frames are used as a backup system. Detailing of rigid full-strength joints can reduce constructability and increase fabrication costs. Astaneh-Asl [6], Alinia et al. [16], Dubinaand Dinu [17] found that existence of shear wall inside moment frame considerably reduces rotation demands on joints, as well as contributes to ultimate capacity of frames which can justify the application of semi-rigid and partial-strength beam-to-column joints. The beneficial effects of the infill may be observed even after its substantial damage, and because of gusset like corner pieces the joints are still not subjected to large rotations. Besides, only few experiments that were carried out [18] mention the possibility of application of composite infills in frames with semi-rigid and partialstrength beam-to-column joints.

Systems using composite panels possess high stiffness and ability to overtake significant lateral forces that usually occur during medium size and large seismic events, particularly within tall buildings. Due to these facts, systems with composite panels are designed to be able to achieve high level of ductility, as well as to have sufficient overstrength. This desired behaviour is achieved by arrangement of ductile failure modes occurrence before brittle ones, and by plastic hinge formation primarily in non-gravity carrying elements. Subsequent formation of plastic hinges in gravity carrying members is allowed, but caution has to be taken to prevent formation of the softstorey plastic mechanism. Preferred failure modes as well as their hierarchical order arrangement are, in detail, given in [6], where it is implied that none of the failure modes are allowed to occur under service lateral loads i.e. actions from seismic load combinations. It is also important to mention that all buckling failure modes, depending on whether they occur in elastic or inelastic region are considered brittle or ductile failure modes, respectively. Failure modes where plastic hinge is formed at the top of the column of the highest storey or at the column base are considered ductile, and are therefore allowed [6].

\section{Design guidelines}

Due to lack of comprehensive data obtained from experimental research design guidelines for composite plate shear walls provided in norms are relatively scarce. In accordance with the assumptions that composite panel should resist all the lateral forces exerted on the structure, and be able to dissipate most of that energy either through inelastic deformation of the panel itself or other parts of the structure where such behaviour is allowed, it is quite logical to approach the problem of composite shear wall design from that very composite panel. Presented below are design guidelines accepted by leading world norms [4, 5] together with relevant studies conducted up to date which aim to further improve the given guidelines, or expand mode and scope of these systems. Design guidelines given in both referenced norms are generally the same, noting that the ones from US norm [4] are somewhat more extensive, leaving the designer of these systems with smaller number of opened issues.

\subsection{Composite plate}

As previously mentioned, design resistance of composite plate given in norm does not take account of the concrete compression diagonal carrying capacity. This negligence, although conservative, is justified given that shear strength of RC plate is small, and therefore has no significant effect on the overall resistance. Due to this, resistance of the composite panel corresponds to the full yield strength of the steel plate obtained through usual, well-known, equation.

Since the discussed steel plate is very slender achievement of full shear resistance requires adequate out of plane restrains that will be able to prevent local or global loss of stability. Besides the remark in [4] which states that "conformance to this requirement shall be demonstrated with an elastic plate buckling analysis" there are no other explicit provisions whose fulfilment will ensure yielding of the plate in shear before the onset of instability.

In order to demonstrate that and adequate stiffening is provided Astaneh-Asl [6] proposes to transform RC encasement to equivalent vertical and horizontal steel stiffeners in accordance with Fig. 3.

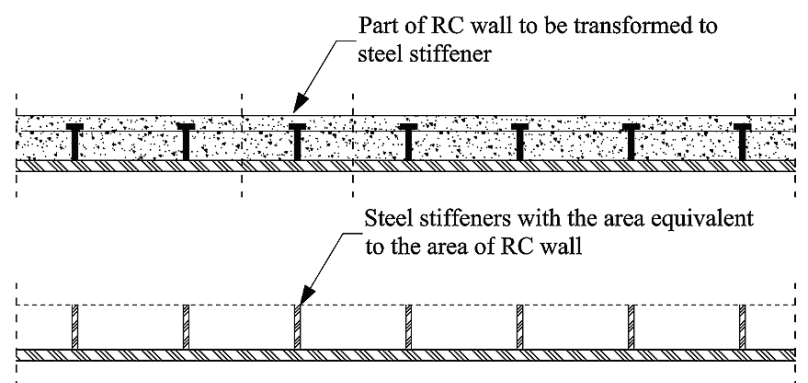

Figure 3 Composite panel and steel panel with equivalent stiffeners [6]

Global stability of the transformed plate geometry should then be checked using elastic buckling theory of stiffened or orthotropic plates. The design guide [19] indicates that the rigidity requirement of stiffeners, ensuring sufficient web stability of plate girders given [4], can adequately be applied to the transformed composite panel. Therefore, the minimum stiffness of the stiffeners is obtained through Eq. (1), and from it equivalent concrete stiffness can be determined (taking account of lower elastic modulus of concrete).

$$
I_{s t} \geq a t_{w}^{3} j
$$

where: $j=2,5(b / a)^{2}-2 \geq 0,5 ; a, b \quad$ - vertical and horizontal spacing between stiffeners/connectors, respectively; $t_{w}$ - thickness of the steel plate. 
Conditions ensuring local plate stability, between fasteners, are also not given in currently valid norms [4, 5], although they existed in previous releases of the US norm [20]. It is proposed to check local stability of the subpanels in accordance with the conditions given for compact webs of plate girders exposed to pure shear according to Eq. (2).

$$
\frac{b}{t_{w}} \leq 1,10 \sqrt{\frac{k_{v} E}{f_{y k}}},
$$

where: $k_{v}=5+\frac{5}{(a / b)^{2}}$.

Due to lack of experimental data carried out on systems using composite plate infill some of the requirements in norms that have to be satisfied throughout design process are not directly obtained for these systems. Such requirements mostly refer to the composite panel itself, and are given here as:

- Steel plate thickness of less than $10 \mathrm{~mm}$ in not permitted [4]

- Minimal concrete thickness shall be $100 \mathrm{~mm}$ when concrete is provided on both sides of the steel plate and $200 \mathrm{~mm}$ when concrete is provided on only one side of the steel plate $[4,5]$

- Reinforcement ration of RC plate in both directions shall not be less than $0,25 \%[4,5]$

- Maximum spacing between reinforcement bars shall not exceed $450 \mathrm{~mm}$ [4]

- Steel plate shall be continuously connected on all edges to boundary (frame) members $[4,5]$.

\subsection{Connection of concrete panel to steel plate}

Connection of the RC panel to the steel plate is dependent on the way the $\mathrm{RC}$ panel is made. Therefore, if the RC panel is cast-in-place the shear connection is usually accomplished through headed steel studs (Fig. 4a) or some other type of stud (e.g. hooked steel studs as shown in Fig. 4b), while for precast concrete plate interconnection is assured through bolts (Fig. 4c).

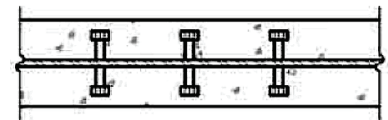

a)

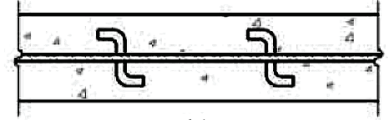

b)

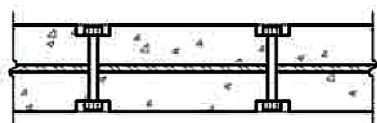

c)

Figure 4 Types of shear connectors between RC and steel plate [19]

According to [4] shear connectors shall be designed to resist the tension force resulting from inelastic local buckling of the steel plate. At the same time collective shear resistance of connectors shall be greater than expected shear strength of the steel plate or reinforced concrete panel, whichever turns out to be smaller. Fig. 5 shows section forces active when inelastic plate buckling occurs, where by setting these in equilibrium one can determine the tensile force acting in each shear connector according to Eq. (3) [6].

$F_{t, E d}=\frac{4 M_{p l, R d}}{b}=\frac{a t_{w}{ }^{2} f_{y d}}{b}$

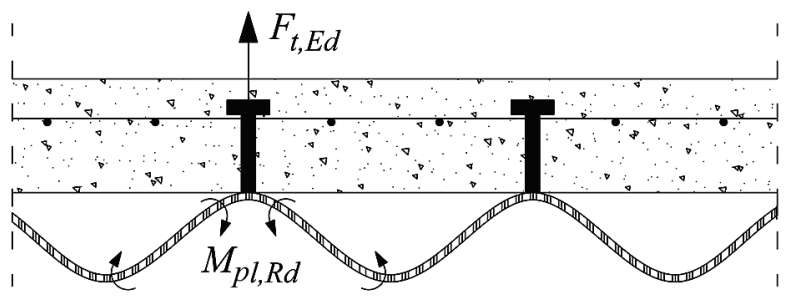

Figure 5 Tension force in shear connector [6]

\subsection{Connection of steel plate to boundary elements}

This connection is usually achieved through application of the fish plate which is welded directly to the boundary members. Direct connection of steel plate to the frame elements has mostly research application i.e. where laboratory specimens are produced when strictly controlled environment conditions are present.

Current norms allow either welded or bolted (slipresistant high-strength bolts only) connection variant, where the former one has been more frequently used in up to date conducted experimental research.

All parts of these connections (fish plates, welds, and bolts) shall be designed such that full yield strength of the plate can be developed [5] i.e. that expected shear yield strength of the steel plate can be achieved according to Eq. (4)[4].

$R_{y} A_{p l} f_{y k} / \sqrt{3}$

where: $R_{y}$ - ratio of expected to nominal steel yield strength.

Value of $R_{y}$ coefficient is given in the US norm [4] and its value is between 1,1 to 1,6 depending on the given nominal steel yield strength as well as on the type of steel product. In European norm [5] this coefficient corresponds to overstrength factor, $\gamma_{o v}$, whose value might be given in national annex or otherwise the recommended value of 1,25 can be adopted.

\subsection{Boundary members (beams and columns)}

In case when the composite infill reaches full shear strength stresses developed in frame elements should remain in the elastic range. This assumption implies their design to accommodate expected shear resistance of the panel which is given by Eq. (4). In the absence of the gap between concrete encasement and boundary elements or when it is assumed that, for large seismic events, the gap will be closed it is necessary to account for the additional transverse force in the design of the frame elements. This transverse force is the consequence of activation of compressive diagonal within the RC panel.

When plastic behaviour of boundary members is considered it is given that beams are allowed to form plastic hinges at their ends, while plastic hinges on 
columns might form at their base or at their top if they are part of the building highest floor.

The frame elements, according to [4], have to meet requirements of highly ductile members, which are related to limiting width-to-thickness ratios of their cross-section parts. For rolled or built-up I-shaped sections these requirements correspond to the requirements for compression flange of class 1 and for web in compression of class 3 given in [21]. Such classification of highly ductile members is somewhat relaxed when compared to the requirements of [22] where all cross-section parts (flange and web) should satisfy local slenderness limits prescribed for class 1 .

Astaneh-Asl [6], additionally, provides simple rule of thumb where boundary elements web thickness should be equal or greater than the thickness of composite panel steel plate.

\subsection{Beam-to-column joint}

The US norm [4] as opposed to European [5] explicitly states necessary joint characteristics. Accordingly, joints shall be detailed to satisfy the requirements of rigidity and full-strength, while rotation capacity limitations should correspond to conditions for ordinary moment frames joints. Such frames, according to the European norm [5], would be classified as frames with low dissipative structural behaviour (DCL), where neither the US nor the European norms prescribe specific limitations for their joint rotation capacity. This represents a relaxation of the requirements for joint rotation capacity, which initially had to be executed to satisfy provisions for special moment frames where the rotation capacity of $0,04 \mathrm{rad}$ has been required. As the result of conducted research it has been found out that existence of composite infill, which is continuously connected to the frame members, prevents joint rotation, and therefore reduces the requirements for its high rotation capacity.

In accordance with the desired behaviour of the system, which predicts formation of plastic hinges in beams, joints have to be adequately designed. Therefore, joint design moment resistance, $M_{j, R d}$, has to be greater or equal to expected beam design plastic moment resistance, $M_{p l, b, R d}$ :

$$
M_{j, R d} \geq 1,1 \gamma_{o v} M_{p l, b, R d}
$$

While design shear force resistance must be greater than the sum of design value of shear force due to the non-seismic actions and design shear force occurring in beams due to formation of plastic hinges at both its ends:

$$
V_{j, R d} \geq V_{E d, G}+V_{E d, M}=V_{E d, g}+2\left\lfloor 1,1 \gamma_{o v} M_{p l, b, R d}\right\rfloor / l_{b l},
$$

where: $l_{b l}-$ clear length of the beam.

Design actions taken into account for joint resistance calculation in Eq. (5) and Eq. (6) are conservative, therefore design can be conducted for maximum moment and corresponding shear that can be transferred to the joint by the system, including the effects of material over strength and strain hardening [4].
To preclude formation of soft storey mechanism both norms [4, 5] prescribe satisfaction of virtually same requirements.

Considering the resistance of the entire system through beam-to-column joints of frames with steel infills [23] it has been detected that there is no significant difference between strength capacity of systems with moment-resisting and simple joints, but the application of moment joints will, in the end, allow for greater energy dissipation capacity [24].

\section{$5 \quad$ Hitherto conducted research}

Since composite plate shear wall system is relatively new type of vertical stabilisation, it is expected that the number of conducted researches is relatively scarce. Besides its novelty, another reason for this are rather high costs of experimental testing which requires a vast number of specimens, as well as complex technical capabilities of facilities capable of carrying out such tests.

\subsection{Astaneh-Asland Zhao [2, 6, 25, 26]}

First experiments on systems with composite plates inserted within steel frames were conducted at the end of last century. In his report [6], Astaneh-Asl gave detailed preview of prescribed design guidelines of these systems, as well as the results of experimental test of two 1:2 scale four storey one bay specimens. In his work he also proposed new type of the system which predicts existence of the gap between the RC encasement and the boundary members, where such system, termed innovative, would be able to significantly reduce damage of the RC plate occurring during low and medium size seismic events. The gap existence will reduce system stiffness, making it to attract less lateral force during seismic ground motion. At the same time it can be shown that for small and more frequent seismic events (the ones with shorter return period) the steel plate alone will be able to provide enough resistance for most of the horizontal action and its stiffness will be sufficient to control interstorey drifts. During these periods RC slab serves only as stiffener preventing occurrence of steel plate instability within the elastic range. In case of large earthquakes (ones with longer return period) due to larger horizontal displacements, the gap will be closed, thereby activating the compression diagonal within the $\mathrm{RC}$ plate. Participation of RC plate will increase system stiffness which may prove to be very useful in reduction of excessive drifts and second-order effects on the structure.

Test results showed that both specimens preformed in very ductile manner, where interstorey drift of $0,04 \mathrm{rad}$ was reached with no loss of shear strength, while for interstorey drifts of $0,05 \mathrm{rad}$ specimens were still able to carry $80 \%$ of the maximum shear force attained during testing. Detailed examination of the specimens after testing showed that inelastic plate buckling occurred locally, between shear connectors, what is in accordance with the desired behaviour. It is from these results evident that RC plate has no significant impact on resistance capacity, nor does it excessively influence stiffness of the system. In addition, higher energy dissipation capability is the result of much greater damage of RC slab, resulting in 
the unstable behaviour of the system, as can be seen from specimens envelope curves presented in Fig. 6.

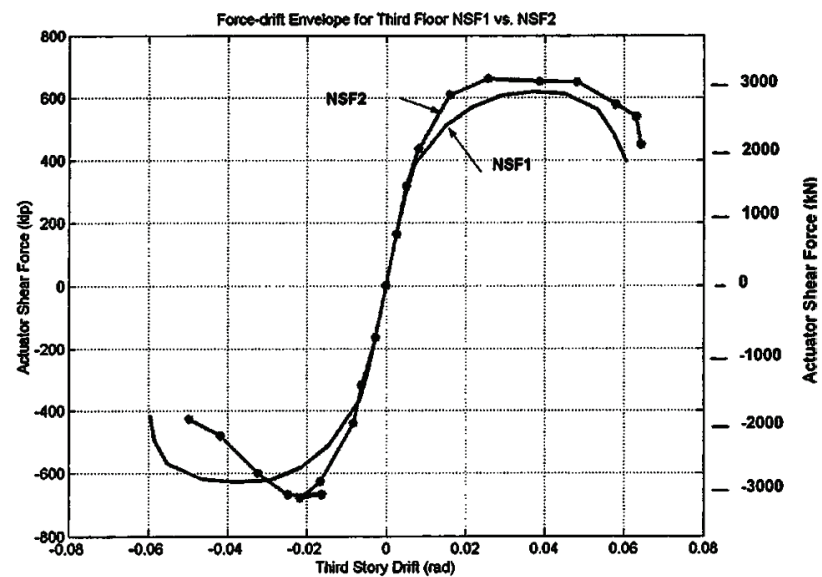

Figure 6 Envelope curves (NSF1-with gap; NSF2-without gap) [6]

Fracture of the steel plate started from its corners where the continuity of the connection between the plate and the boundary elements was interrupted. Fig. 7 shows detailing of the beam-to-column moment connection, with the solution for joint between the steel plate and the frame. As a detailing solution which would reduce the discontinuity Park et al. [27] proposed enhanced detail as given in Fig. 8a, while Choi and Park [15] proposed dislocation of the fish plate welded connection towards beam mid-span in order to prevent early fracture due to stress concentration at the joints as shown in Fig. 8b.

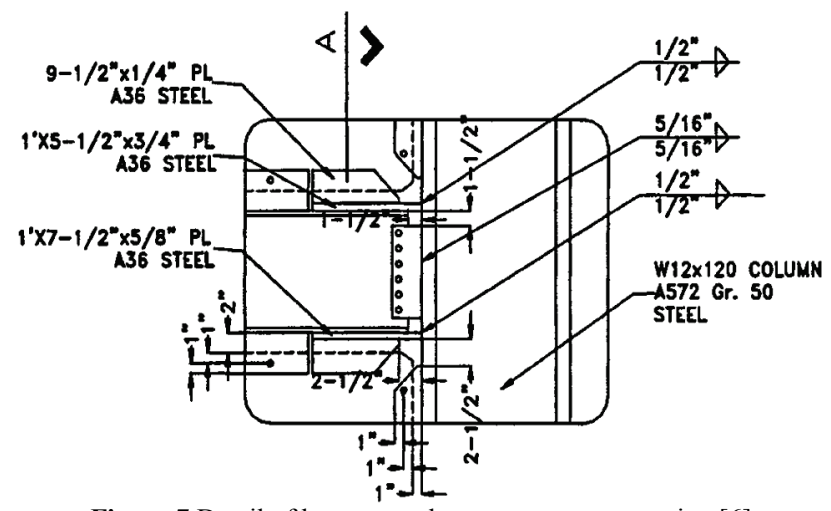

Figure 7 Detail of beam-to-column moment connection [6]

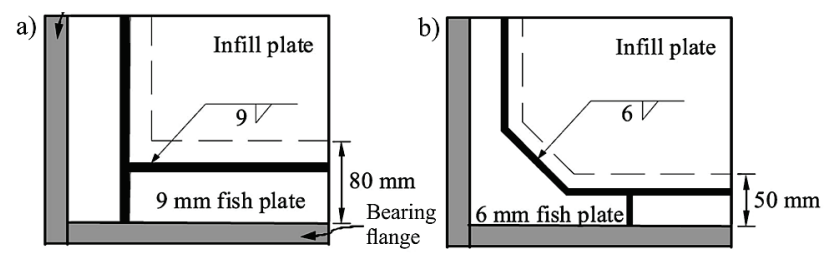

Figure 8 Connection details of fish plates [15, 27]

Zhao [25] establishes numerical FEM model to perform parametric pushover analyses in order to identify the key design parameters. Numerical models were, firstly, verified with the experimental data where good agreement of the results was obtained. Parametric analysis confirmed that increasing steel plate thickness can be a very effective way to strengthen the whole system, but care must be taken in order to prevent premature failure which might occur if the boundary columns do not have enough stiffness. Similarly, the use of higher steel strength would also increase the system resistance, while the use of higher strength concrete would have no significant effect on the system overall behaviour.

\subsection{Sun et al. [28]}

This paper proposes an analytical model for composite plate shear walls that is an extension of previously available tension strip model proposed in 1983 in [29], whereby this model consists of two groups of diagonal parallel (tension and compression) strips as given in Fig. 9. Basic assumption, in determination of the compression strip strength was existence of the gap between the concrete panel and boundary members, which therefore precludes activation of the compression diagonal leaving $\mathrm{RC}$ panel only with the function of stiffener restraining steel plate out-of-plane buckling. In order to determine the compressive strength of the strips one assumes full strength of the tension strips resulting from the plate diagonal tension filed strength which is then subtracted from the plate full shear strength. This assumption yields with compression strip strength which is only $20 \%$ of the tension strip strength. To simulate real hysteretic behaviour of the composite plate shear wall bilinear Clough model was adopted for the strips in the analytical model. Through conduction of parametric analyses the influence of characteristic parameters on the analytical model behaviour has been determined, and ultimately the model is validated with the experimental results. This simple model seems to be suitable for rapid evaluation of composite plate shear wall system behaviour, but it needs further validation against greater number experimental results

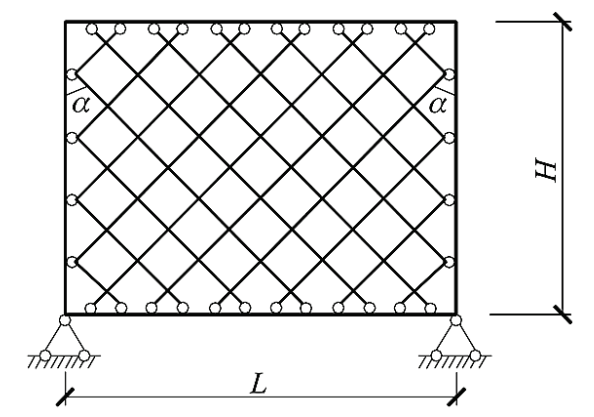

Figure 9 Model with tension and compression strips [28]

\subsection{Arabzadeh et al. [30]}

Composite plate shear wall resistance is dependent on steel plate shear yielding occurrence before its global or local instability mode is reached. For this reason, proper determination of the critical buckling force is one of the most important steps in design of these stabilisation systems. In this paper the authors have used energy methods to establish values of elastic unilateral buckling coefficients of plates in state of pure shear, depending on the plate span, height, and number of shear connectors between steel plate and RC panel. Obtained theoretical results are in good agreement with the experimental findings. Calculated values can be applied to determine the required number of shear connectors which will provide desired behaviour of the composite plate. This paper has also shown that rigidity of the $\mathrm{RC}$ panel has 
insignificant effect on the value of the critical buckling force, and for that matter on the corresponding buckling coefficients. It has also been found that if the panel aspect ratio is greater than 1 , the critical force will decrease, whereby its reduction is more significant for panels with greater number of shear connectors. It is therefore recommended that panels be square shaped.

\subsection{Arabzadeh et al. [3]}

Here, experimental testing of one bay one and three storey height specimens in two phases has been performed. Specimens of both phases are designed to have a gap between RC plate and frame elements, whereby the gap size is calculated such that no interaction occurs up to the specimen failure point. Although specimen scales vary between 1:3 and 1:4 all specimens used RC plate with real scale thickness of $120 \mathrm{~mm}$.

In the first phase monotonic testing of one story specimens is conducted. Tests of such short specimens which use simple beam-to-column connections are therefore in the state of pure shear, and seek to assess the impact of various parameters on composite panel behaviour. It has been found that reduction of the number of shear connectors reduces the critical buckling force, that the percentage of reinforcement within the RC plate has no significant effect on the behaviour, and that application of the RC encasement on both sides of steel plate increases shear resistance of the infill. Results from the first testing phase provided the base for decision on the parameters of the second testing phase.

In the second test phase cyclic loading of one and three storey specimens with moment beam-to-column joints has been conducted. RC plate in this phase was made using high strength concrete due to the fact that $\mathrm{RC}$ plate, made of normal strength concrete, from the first phase suffered significant damage. Evaluated parameters of one story specimens were existence of RC plate on one or both sides, as well as direction of reinforcing bars $\left(45^{\circ}\right.$ rotation), while parameters of three storey specimens were presence of the gap, as well as composite panel span-to-height ratio influence.

Both sided application of RC plate increases resistance and energy dissipation capacity, but reduces system ductility. Although omission of the gap increases system strength it reduces its ductility and energy dissipation capacity. This might be associated with additional force which RC plate, through formation of compression diagonal, transfers onto the columns and thus affects system stability. Increase of system span-toheight ratio reduces the bending stress distribution within the panel. It has been observed that shear connectors (in this case bolts) in the middle of the panel are subjected only to shear actions, while outer ones exhibited interaction of shear and axial (tensile) force. In addition to the tests that were carried out, this paper also elaborates on the guidelines for design of each system component.

This study confirms the previously known fact that shear walls in lower floors of taller buildings are subjected to shear, $\tau_{s}$, and normal, $\sigma_{b}$, stresses as it is shown in Fig. 10a. Normal stresses occur as a result of the overturning moment action.
To obtain correct spacing of shear connectors which will ensure sufficient steel plate stability, it is necessary to account for given stress distribution. It is therefore proposed to calculate required ratio, $b / t_{w}$, using Eq. (7) accounting for Von-Mises yield criterion as given in [31]. In case of pure shear state $b / t_{w}$ ratio may be calculated according to Eq. (2).

$$
\frac{\sigma_{c}}{\sigma_{c r}}+\left(\frac{\tau}{\tau_{c r}}\right)^{2}=1,0
$$

where: $\sigma_{c r}, \tau_{c r}$ - elastic critical buckling stress of plate in compression and shear, respectively.

Normal stresses resulting from RC plate self-weight may be neglected since, in respect to other stresses, their influence is insignificant.

Beam stress distribution may be assumed as given in Fig. 10b. It is evident that all the stresses present on an intermediate beam cancel each other out, except the stresses that arise from the vertical loads, $\sigma_{v, i}$. Therefore, foundation beam is exposed to significant shear stresses, as well as stresses due to overturning moment and vertical loads. In contrast, roof beam is exposed only to shear stresses resulting from the infill. Assurance of good seismic behaviour assumes composite plate yielding before formation of plastic hinges within beam length, and according to that assumption beam design forces might be calculated using Eq. (8) and Eq. (9).

$$
\begin{aligned}
& P_{b}=\left(\sigma_{b, i-1} t_{w, i-1}-\sigma_{b, i} t_{w, i}\right) \cdot l, \\
& M_{b}=\frac{\left(\sigma_{b, i-1} t_{w, i-1}-\sigma_{b, i} t_{w, i}\right) \cdot l^{2}}{8}+\frac{\sigma_{v, i} \cdot l^{2}}{12} .
\end{aligned}
$$

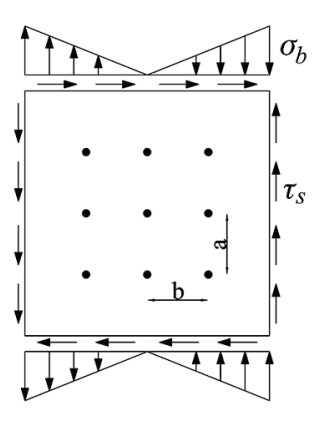

a)

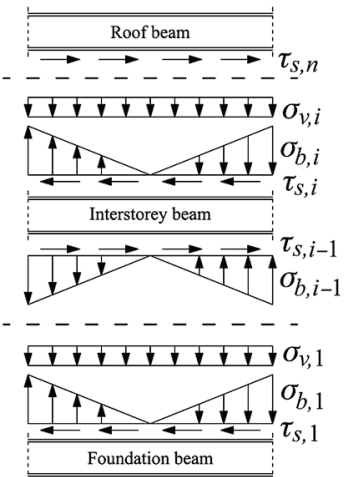

b)

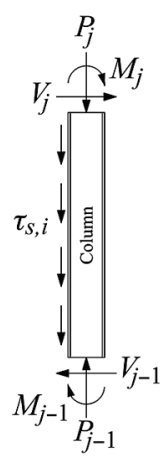

c)
Figure 10 Preview of the stress distribution on the members of composite plate shear wall system [3]

If the composite plate is correctly designed (yielding occurs before buckling) axial force appearing within the frame column would be equal to sum of vertical loads and shear stresses from panel as presented in Fig. 10c, where its value might be determined through Eq. (10). The existence of transverse column loading, $V_{c s}$, causing additional bending according to Eq. (11), is possible only if concrete compression diagonal is activated, which assumes there is no gap between RC plate and boundary members. 


$$
\begin{aligned}
& P_{c}=\sum_{i=1}^{n}\left(\tau_{S, i} t_{w, i}\right) \cdot h+\sum_{i=1}^{n-1} \frac{\sigma_{v, i} \cdot l}{2}, \\
& M_{c}=\frac{V_{c S} \cdot h^{2}}{12} .
\end{aligned}
$$

Transverse force, $V_{c s}$, may be calculated as given in [32]. Since most of the specimens tested up to date had the gap the details of transverse force determination would, therefore, be omitted in this paper.

Finally, conclusion can be drawn that by appropriate design of composite plate and selection of shear connectors, i.e. by appropriate values of $b / t_{w}$ the smallest amount of force is transmitted from the panel to the boundary members, which is not the case when only steel infill is used.

\subsection{Guo et al. [33]}

Authors conducted experimental testing of frames with steel and composite plates. The boundary elements consisted of concrete-filled circular hollow section steel columns and steel beams. The tests were conducted on specimens fabricated with 1:3 scale, where RC plate was placed on both sides of steel one, and the gap between $\mathrm{RC}$ encasement and boundary members was present. Often times, presence of the gap, can be detrimental for the part of the steel plate that remains unstiffened, called unrestrained strip. For that reason, buckling usually appears in this unrestrained part of the plate, and ultimately leads to the plate tearing initiation which is generally developing from the plate corners. Therefore, this paper proposes new detailing of the connection between the composite panel and fish plate that will preclude existence of the unrestrained strip as can be seen in Fig. 11.
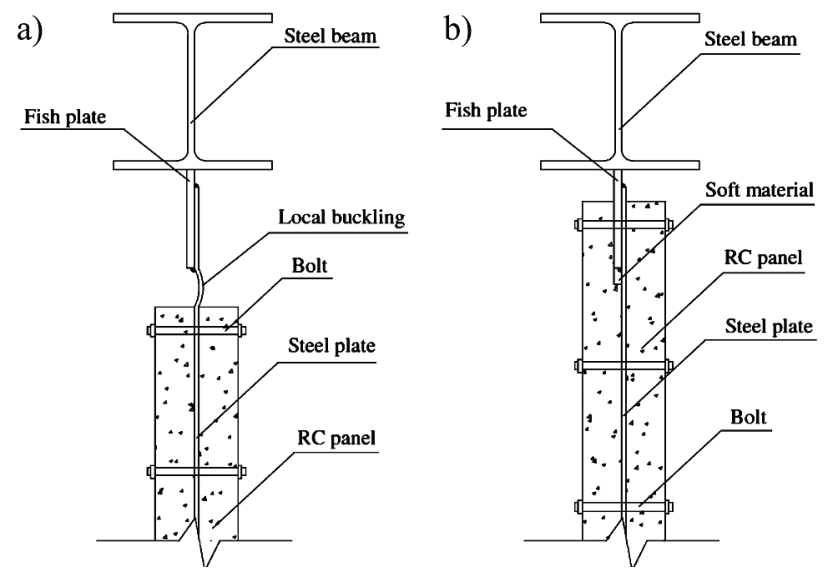

Figure 11 a) Traditional connection detail; b) Innovative connection detail [33]

Throughout evaluation of the experimental results it can be shown that systems with this new connection detail have sufficient ductility and energy dissipation capacity. It has also been confirmed that application of the proposed detail prevented premature failure of the steel plate.

\subsection{Ayazi et al. [34]}

This paper uses numerical models to determine how spacing of shear connectors between RC and steel plate influences main parameters of the composite plate shear wall system. The numerical method implements pushover analysis to obtain the behaviour of specimens that have no gap between RC plate and the frame, and use fully rigid beam-to-column joints. Two groups of models, using $2 \times 2$ and $3 \times 3$ shear connector arrangement, have been examined. Prior to the conduction of the parametric analysis, proposed numerical model was verified against experimental data, and good agreement of the results has been obtained. The study confirmed that increase of shear connector spacing can have positive effects on the system behaviour, but only up to a specified point. Namely, small spacing of shear connectors in given arrangement scheme, will force local buckling of the panel to occur in its outside subpanels, while the central subpanels will be sufficiently stiffened. Gradual connector spacing increase can ultimately reach a value where local buckling will be shifted to occur in the central subpanels of the plate. In the meantime, it can be observed that spacing of connectors results in the tension force increase within the outer connectors, while it has almost insignificant influence on the axial force within the central shear connector. Accordingly, it has been established that the ratio of the tensile forces between central and outer connectors does not exceed value of 0,5. Results also confirm the fact that spacing of shear connectors within the composite plate shear walls, that do not exercise the gap between the RC plate and frame, has no effect on the initial stiffness within the elastic range.

\subsection{Hadzhiyaneva and Belev [18]}

Authors investigate the behaviour of composite plate inserted into frame with semi-rigid partial-strength beamto-column joints. The tested specimens were of 1:4 scale, and have been constructed with the gap between RC plate and the boundary frame. Detail of the beam-to-column joint is given in Fig. 12. Results show that the implemented partially-restrained joints possess adequate rotation capacity according to $[4,5]$. Although shear walls executed with fully-restrained joints have optimal amount of strength, ductility, and energy dissipation capacity, it has been shown that application of partially-restrained joints can lead to desired behaviour of the system, and due to that they can be appropriate for seismic retrofit of existing structures with low ductility.

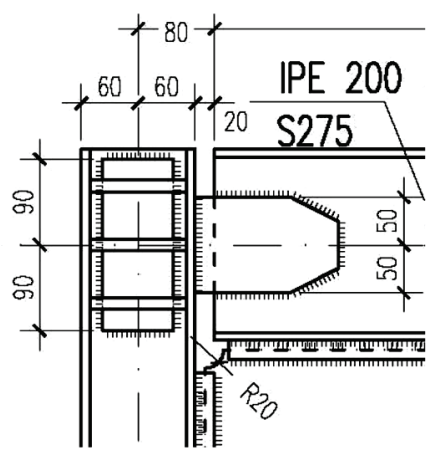

Figure 12 Beam-to-column joint detail [18] 


\section{Conclusion}

Based on the facts stated within the paper it can be concluded that this kind of vertical stabilisation lacks comprehensive research which would cover all aspects affecting their resistance, and, generally, their behaviour. Expensive and complicated laboratory testing are obstacles to the existence of the vast amount of data required to conduct quality statistical and probabilistic analyses. Therefore, the aim of this work is to indicate the current state of the art which would be used to provide guidelines for further research.

\section{References}

[1] Astaneh-Asl, A. Seismic Behavior and Design of Steel Plate Shear Walls. // Steel TIPS Report, Structural Steel Educational Council, Moraga, CA, 2001.

[2] Zhao, Q.; Astaneh-Asl, A. Cyclic behavior of Traditional and Innovative Composite Shear Walls. // Journal of Structural Engineering. 130, 2(2004), pp. 271-284. DOI: 10.1061/(ASCE)0733-9445(2004)130:2(271)

[3] Arabzadeh, A.; Soltani, M.; Ayazi, A. Experimental investigation of composite shear walls under shear loadings. // Thin-Walled Structures. 49, 7(2011), pp. 842854. DOI: 10.1016/j.tws.2011.02.009

[4] AISC. Seismic Provisions for Structural Steel Buildings. American Institute of Steel Construction. Chicago, IL, 2010.

[5] CEN. Eurocode 8. Design of structures for earthquke resistance - Part 1: General rules, seismic actions and rules for buildings. European Committee for Standardization, Brussels, Belgium, 2004.

[6] Astaneh-Asl, A. Seismic Behavior and Design of Composite Steel Plate Shear Walls. // Steel TIPS Report, Structural Steel Educational Council, Moraga, CA, 2002.

[7] Wagner, H. Flat Sheet Metal Girders with Very Thin Metal Webs, Part I - General Theories and Assumptions. Technical Memorandum, No. 604, National Advisory Committee for Aeronautics, Washington, DC, 1931.

[8] Kuhn, P.; Peterson, J. P.; Levin, L. R. A summary of diagonal tension: Part II - Experimental evidence. Technical Memorandum, No. 2662, National Advisory Committee for Aeronautics, Washington, DC, 1952.

[9] Kuhn, P. Stressen in aircraft and shell structures. McGrawHill Book Co., New York, NY, 1956.

[10] Basler, K. Strength of plate girder in shear. // Journal of Structural Division. 87, 7(1961), pp. 151-180.

[11] Thorburn, L. J.; Kulak, G. L.; Montgomery, C. J. Analysis of steel plate shear walls. Structural Engineering Report, No. 107, University of Alberta, Edmonton, Canada, 1983.

[12] Kulak, G. L. Behavior of steel plate shear walls. // Proceedings of the Int. Engineering Symposium on Structural Steel, AISC, Chicago, IL, 1985.

[13] Timler, P. A.; Kulak, G. L. Experimental study of steel plate shear walls. Structural Engineering Report, No. 145, University of Alberta, Edmonton, Canada, 1987.

[14] Berman, J. W.; Bruneau, M. Steel Plate Shear Walls Are Not Plate Girders. // Engineering Journal. 41, 3(2004), pp. 95-106.

[15] Choi, I. R.; Park, H. G. Ductility and Energy Dissipation Capacity of Shear-Dominated Steel Plate Walls. // Journal of Structural Engineering. 134, 9(2008), pp. 1495-1507. DOI: 10.1061/(ASCE)0733-9445(2008)134:9(1495)

[16] Alinia, M. M.; Jamshidi, A. H.; Habashi, H.R. The Gusset Plate Effect in Steel Plate Shear Wall Systems. // Proceedings of $3^{\text {rd }}$ International Conference on Integrity, Reliability and Failure, Porto, Portugal, 2009.
[17] Dubina, D.; Dinu, F. Experimental evaluation of dual frame structures with thin-walled steel panels. // Thin-Walled Structures. $78(2014), \quad$ pp. 57-69. DOI: 10.1016/j.tws.2014.01.001

[18] Hadzhiyaneva, I.; Belev, B. Behaviour of Steel Plate Shear Walls with Buckling-Restrained Web Panels. // Proceedings of Second European Conference on Earthquake Engineering and Seisimology, Istanbul, Turkey, 2014, pp. $1-10$.

[19] Sabelli, R.; Bruneau, M. Steel Design Guide 20 - Steel Plate Shear Walls. AISC, USA, 2007.

[20] AISC. Seismic Provisions for Structural Steel Buildings. American Institute of Steel Construction. Chicago, IL, 2005.

[21] AISC. Specification for Structural Steel Buildings. American Institute of Steel Construction. Chicago, IL, 2010.

[22] CEN. Eurocode 3. Design of steel structures - Part 1-1: General rules and rules for buildings. European Committee for Standardization, Brussels, Belgium, 2005.

[23] Caccese, V.; Elgaaly, M.; Chen, R. Experimental Study of Thin Steel-Plate Shear Walls under Cyclic Load. // Journal of Structural Engineering. 119, 2(1993), pp. 573-587. DOI: 10.1061/(ASCE)0733-9445(1993)119:2(573)

[24] Tromposch, E. W.; Kulak, G. L. Cyclic and Static Behaviour of Thin Panel Steel Plate Shear Walls. Structural Engineering Report, No. 145, University of Alberta, Edmonton, Canada, 1987.

[25] Zhao, Q. Experimental and Analytical Studies of Cyclic Behavior of Steel and Composite Shear Wall Systems. PhD dissertation, University of California, Berkeley, CA, 2006.

[26] Zaho, Q.; Astaneh-Asl, A. Seismic Behavior of Composite Shear Wall Systems and Application of Smart Structures Technology. // International Journal of Steel Structures. 7, 1(2007), pp. 69-75.

[27] Park, H. G.; Kwack, J. H.; Jeon, S. W.; Kim, W. K.; Choi, I. R. Framed steel plate wall behavior under cyclic lateral loading. // Journal of Structural Engineering. 133, 3(2007), pp. 378-388. DOI: 10.1061/(ASCE)0733-9445(2007)133:3(378)

[28] Sun, F. F.; Liu, G. R.; Li, G. Q. An Analytical Model for Composite Steel Plate Wall. // Proceedings of the 14th World Conference on Earthquake Engineering, Beijing, China, 2008.

[29] Timler, P. A.; Kulak, G. L. Experimental Study of Steel Plate Shear Walls. Structural Engineering Report, No. 114, University of Alberta, Edmonton, Canada, 1983.

[30] Arabzadeh, A; Moharami, H.; Ayazi, A. Local elastic buckling coefficients of steel plates in composite steel plate shear walls. // Scientia Iranica. 18, 1(2011), pp. 9-15. DOI: 10.1016/j.scient.2011.03.002

[31] Trahair, N. S.; Bradford, M. A. The behaviour and design of steel structures to AS4100, 3rd edition.Taylor \& Francis, London, UK, 1998.

[32] ACI. Building Code Requirements for Structural Concrete (ACI 318-11). American Concrete Institute. Farmington Hills, MI, 2011.

[33] Guo, L.; Li, R.; Rong, Q.; Zhang, S. Cyclic behavior of SPSW and CPSW in composite frame. // Thin-Walled Structures. 51, 2(2012), pp. 31-52.

[34] Ayazi, A.; Ahmadi, H.; Shafaei, S. The Effects of Bolt Spacing on Composite Shear Wall Behavior. // World Academy of Science, Engineering and Technology. 6 (2012), pp. 1069-1076. 


\section{Authors' addresses}

Ivan Ćurković, dipl. ing. grad.

Faculty of Civil Engineering, University of Zagreb,

Kačićeva 26, 10000 Zagreb, Croatia

E-mail: icurkovic@grad.hr

Prof. dr. sc. Ivica Džeba, dipl. ing. građt.

Faculty of Civil Engineering, University of Zagreb,

Kačićeva 26, 10000 Zagreb, Croatia

E-mail: ivci@grad.hr 